\title{
The high effect of chemomobilization with high-dose topside and G-CSF in autologous hematopoietic peripheral blood stem cell transplantation (Single centre experience)
}

\author{
Sebnem Izmir Guner ${ }^{*}$, Mustafa Teoman Yanmaz ${ }^{2}$, Ahmet Selvi $^{3}$ and Cigdem Usul ${ }^{4}$ \\ ${ }^{1}$ Haematology, Istanbul Kemerburgaz University, Kolan Şişli International Hospital, Istanbul, Turkey \\ ${ }^{2}$ Medical Oncology, Kolan Şişli International Hospital, Medical Faculty, Istanbul, Turkey \\ ${ }^{3}$ Pulmonary Medicine, Istanbul Kemerburgaz University, Medical Faculty, Istanbul, Turkey \\ ${ }^{4}$ Medical Oncology, Istanbul Research and Education Hospital, Istanbul, Turkey
}

\begin{abstract}
Autologous hematopoietic stem cell transplantation (auto-HSCT) provides hematopoietic support after high-dose chemotherapy and is the standard of care for patients with multiple myeloma (MM) or chemo sensitive relapsed high or intermediate grade non-Hodgkin's lymphoma (NHL) and Hodgkin's lymphoma (HL). However, yields of hematopoietic stem cells vary greatly between patients, and the optimal strategy to mobilize hematopoietic stem cells into peripheral blood for collection has not been defined. We investigated the efficacy and safety of chemo mobilization with an intermediate dose etopside (VP-16; 200 mg/m2 on days 1-3) and granulocyte-colony stimulating factor (G-CSF) $(5 \mu \mathrm{g} / \mathrm{kg}$ twice daily from day 4 through the final day of collection). We reviewed our institutional experience with 91 patients (71 MM, $12 \mathrm{HL}, 8 \mathrm{NHL}$ ) mobilized with this regimen. VP-16 and G-CSF resulted in successful mobilization in $95.55 \%$ of the patients (on one patient stem cell collection with plerixafor was applied), including 76 patients $(83,52 \%)$ whose stem cells were collected successfully in a single day. Collection was managed between minimum D8 and maximum D17. Patient age, gender, exposure to previous irradiation and chemotherapy, previous mobilization attempts, and disease characteristics were not considered during patient selection. Adverse effects of the regimen included supportive transfusions and fevers requiring hospitalization or intravenous antibiotics. VP-16 and G-CSF appears to be a safe and effective mobilization regimen for patients with multiple myeloma, non-Hodgkin's lymphoma and Hodgkin's lymphoma undergoing autologous stem cell transplantation, producing excellent stem cell yield with the majority of patients requiring 1 day of apheresis
\end{abstract}

\section{Introduction}

Autologous hematopoietic stem cell transportation (auto-HSCT) is the standard of care for patients with multiple myeloma (MM) or chemosensitive relapsed higher intermediate grade non-Hodgkin's lymphoma (NHL) and Hodgkin's lymphoma (HL). Also it provides essential hematopoietic support after the administration of high-dose therapy (HDT) [1-3]. Although MM is an incurable malignancy, autoHSCT used in conjunction with HDT has shown to prolong survival $[4,5]$. The rates of complete response to conventional therapy without auto-HSCT in patients with MM are between 5-15\% [4-7]. AutoHSCT in combination with HDT can increase the rates of complete response to $20-44 \%$ and is associated with a very low incidence of treatmentrelated mortality $[1,7]$.

Auto-HSCT combined with HDT administration after relapse, has shown to prolong the duration of remission in patients with diffuse large B-cell lymphoma and provides these patients with approximately a $45 \%$ probability of long-term diseasefree survival [2]. Auto-HSCT is also used in conjunction with high-dose myeloablative therapy as a salvage treatment for follicular lymphoma. Although controversial, recent data suggest that more than 10 year disease free survival is possible after salvage auto-HSCT for patients with follicular lymphoma and Hodgkin's lymphoma [8]. In addition, auto-HSCT may improve the prognosis in patients with mantle cell lymphoma, specifically when it is used as part of first-line treatment.
The success of auto-HSCT is influenced by a number of factors. The most important one is the dose of reinfused stem cells. Higher stem cell doses are associated with faster plt engraftment (generally defined as plt count $>20 \times 10^{9} / 1$ ), faster neutrophil engraftment (generally defined as ANC $>0.5 \times 10^{9} / 1$ ) [8] and reduction in the need for supportive measures such as transfusions of packed RBCs and plts and administration of prophylactic antibiotics $[8,9]$. In some studies, higher stem cell doses have been associated with higher rates of survival for patients [10]. Other factors that affect collection efficiency and the success of auto-HSCT include patient age, gender, exposure to previous irradiation \& chemotherapy, previous mobilization attempts, and disease characteristics such as the involvement of bone marrow (BM) [11]. Unsuccessful initial stem cell mobilization leads to costly additional mobilization attempts and even may prohibit auto-HSCT $[7,10,11]$. Current regimens to mobilize PBSC for auto-HSCT have

Correspondence to: Sebnem Izmir Guner, Haematology, Istanbul Kemerburgaz University, Kolan Şişli International Hospital, Istanbul, Turkey, E-mail: sebnemizmirguner@gmail.com

Key words: autologous hematopoietic peripheral blood stem cell transplantation, chemomobilization, etopside

Received: February 29, 2016; Accepted: March 18, 2016; Published: March 21 2016 
differing stem cell yields, safety considerations, resource utilization, and levels of contamination of the apheresis product with tumor cells $[2,11]$. The two most common mobilization strategies are using cytokines alone or cytokines after chemotherapy.

Mobilization using FDA approved cytokines alone is generally well tolerated; however, yields are often suboptimal and collection of sufficient numbers of stem cells to support transplantation can be difficult, particularly in patients who have previously been treated with multiple rounds of intensive chemotherapy. The efficiancy of G-CSF alone in certain patient groups is quite good, although there have been several different patient populations identified as difficult to mobilize. "Failure rates" of G-CSF alone have been variably reported between $1 \%$ and $40 \%$. Recently, in large phase 3 studies, only $34 \%$ of patients mobilized with only G-CSF are able to collect $6 \times 10^{6} \mathrm{CD} 34^{+}$cells $/ \mathrm{kg}$ in 2 days of apheresis [12]. In contrast, mobilization with chemotherapy in addition to cytokine has been previously demonstrated to increase stem cell yields at the time of collection [11]. Most of this data has been reported with the use of cyclophosphamide (Cy) in addition to G-CSF, in which stem cell yields and failure rates have been improved in comparison to G-CSF alone. The addition of a myelosuppressive chemotherapeutic agent to a cytokine mobilization regimen improves collections by a factor of 2.5 and can reduce the number of apheresis sessions needed for cell collection $[13,14]$.

Potential disadvantages of adding chemotherapy to mobilization include increased complications such as cytopenias requiring transfusion support, febrile neutropenia requiring hospitalization, and intravenous antibiotics. Further disadvantages are inability to schedule patients for apheresis due to difficulty in predicting peak $\mathrm{PB} \mathrm{CD} 34^{+}$cell recovery, unpredictability regarding the optimal day for stem cell collection $[3,9,15-17]$ and delayed engraftment $[3,11]$.

Conversely, other studies have demonstrated comparable neutrophil and platelet (PLT) engraftment kinetics for patients mobilized with either chemotherapy in combination with cytokines or cytokines alone [3,9,15-17]. Although growth factor mobilization is associated with lower cell yields when compared to chemomobilization, $[3,11,15-17]$ it is also associated with lower toxicity and more predictable mobilization, thereby permitting easy apheresis scheduling. There is available data that support the ability of high-dose etoposide (VP-16) to effectively mobilize progenitor cells [16]. There is also one data about the routine addition of VP-16 to G-CSF in the mobilization of patients with MM [17].

This study was aimed to use an intermediate dose of etoposide (200 $\mathrm{mg} / \mathrm{m}^{2}$ per day for 3 days) to preserve progenitor cell mobilization and antitumor properties while limiting other potential toxicities including myelodysplasia, mucositis, hepatic dysfunction, or prolonged cytopenias associated with higher doses of this or other agents. With this institutional experience we are reporting the safety and efficacy of this regimen.

\section{Materials and methods}

\section{Patients and treatment}

This study is conducted on 91 patients between the ages of 20 and 67 who received mobilization with VP-16 and G-CSF prior to ASCT for MM, NHL and HL at our institution between the years 2010 and 2014. The mobilization regimen consisted of placement of a central apheresis catheter followed by administration of intravenous VP-16 $\left(200 \mathrm{mg} / \mathrm{m}^{2}\right)$ once daily on D1-3. Each VP-16 infusion was diluted to a concentration of $0.5 \mathrm{mg} / \mathrm{mL}$ and infused over 4 hours. G-CSF was administered at a dose of $5 \mu \mathrm{g} / \mathrm{kg}$ twice daily starting on D 4 and continuing through the last day of stem cell collection. Antimicrobial prophylaxis was not given.

Peripheral blood CD $34^{+}$cell counts were checked routinely, except for the patients who to have normal or high total white blood cell counts. Apheresis was initiated when the peripheral blood $\mathrm{CD} 34^{+}$cell count was $>20 / \mu \mathrm{L}[18]$, and all patients had stem cells collected between days 8 and 17 (median day 11,31). CD34 determination was conducted in daily leukapheresis samples before cryopreservation with $10 \%$ dimethylsulfoxide by controlled-rate freezing. Cells were stored at $-196^{\circ} \mathrm{C}$ until thawing for transplantation.

Target volumes were calculated based on an algorithm that includes the patient's weight in kilograms, the peripheral precollection $\mathrm{CD} 34^{+}$count, and the requested cell dose (usually a minmum of 2,39 $\times 10^{6} \mathrm{CD} 4^{+}$cells $/ \mathrm{kg}$ and a maximum of $84,93 \times 10^{6} \mathrm{CD} 34^{+}$cells $/ \mathrm{kg}$ ) (median $33,73 \times 10^{6} \mathrm{CD} 34^{+}$cell $/ \mathrm{kg}$ ). The main goal of the collection was to obtain more than $2,0 \times 10^{6} / \mathrm{kg}$ patient body weight of $\mathrm{CD} 34^{+}$cells. $\mathrm{CD} 4^{+}$cells were determined according to the International Society of Hematotherapy and Graft Engineering Guidelines as previously described. All collections were done using the Fresenius kabi Com.tec.

Platelet transfusions were administered routinely for platelet counts $<10.000$, with higher thresholds used for patients at a higher risk for clinically significant bleeding. ASCT was performed using melphalan ( $200 \mathrm{mg} / \mathrm{m}^{2}$ reduced to $140 \mathrm{mg} / \mathrm{m}^{2}$ for patients with comorbid illness) or BEAM chemotherapy protocol followed by stem cell infusion.

\section{Results}

Between years 2010 and 2014, a total of 91 patients with MM, NHL and HL underwent stem cell mobilization. Collection with VP-16 and G-CSF were followed by ASCT in 91 patients (one patient was collected with plerixafor). Among these, 60 (65,94\%) were male and $31(34,07 \%)$ were female. The median age at the time of transplant was 52,61 years, with a range of 20 to 67 years.

Patients had received several lines of prior treatment for myeloma or lymphoma. 48 patients $(52,75 \%)$ received 1 prior treatment regimen, 37 patients $(40,66 \%)$ received 2 regimens, 3 patients $(3,3 \%)$ received 3 regimens, and 3 patients $(3,3 \%)$ recieved 4 prior regimens. The NHL and HL diagnosed patients were all in remision, MM diagnosed patients were $30(42,25 \%)$ in remision and $41(57,75 \%)$ in very good response position before collecting their stem cell.

Median bone marrow (BM) cellularity prior to mobilization for patients with this information available on chart review was $55 \%$ (range: $60-95 \%$ ), with a median 5\% plasma cell involvement (range: 1-10\%) (Table 1).

On 76 patients $(83,52 \%)$ stem cells were successfully collected after 1 mobilization.

On 76 patients $(83,52 \%)$ stem cells were successfully collected after 1 day of apheresis, 13 patients $(14,29 \%)$ required 2 days of collection, 2 patient $(2,2 \%)$ required 3 days of collection. Patients collected on min. day 8, with the max. Day 17 (median day 11.31).

The median peak peripheral blood $\mathrm{CD} 34^{+}$cell count during the collection period was $193,7 / \mu \mathrm{L}$ and the median collected CD $34^{+}$ cell number was $33,73 \times 10^{6}$ cells $/ \mathrm{kg}$ (range: $2,39 \times 10^{6}-84,93 \times 10^{6}$ ). Viabilite median range was $15,14 \times 10^{6}$ cells $/ \mathrm{kg}$ (range: $2,01 \times 10^{6}-83,76$ $\left.\times 10^{6}\right)$. 
Guner SI (2016) The high effect of chemomobilization with high-dose topside and G-CSF in autologous hematopoietic peripheral blood stem cell transplantation (Single centre experience)

Table 1. Patient characteristics.

\begin{tabular}{|l|c|}
\hline Variable & Number \\
\hline Total & 91 \\
\hline Median Age (range) & $52.61(20-67)$ \\
\hline Male sex (\%) & $60(65.94 \%)$ \\
\hline Female sex (\%) & $31(34.06 \%)$ \\
\hline Number of prior treatment regimens (\%): & \\
\hline 1 & $48(52.75 \%)$ \\
\hline 2 & $37(40.66 \%)$ \\
\hline 3 & $3(3.3 \%)$ \\
\hline 4 & $3(3.3 \%)$ \\
\hline Prior radiation therapy (\%) & $24(26.37 \%)$ \\
\hline $\begin{array}{l}\text { Marrow cellularity percentage prior to mobilization } \\
\text { (range) }\end{array}$ & $55 \%(60-95 \%)$ \\
\hline Marrow disease involvement at mobilization (range) & $5 \%(0 \%-10 \%)$ \\
\hline
\end{tabular}

Table 2. Mobilization efficacy.

\begin{tabular}{|l|c|}
\hline Criteria & Number \\
\hline Successful collection after 1 mobilization & $76(83.52 \%)$ \\
\hline Patients collecting $>10 \times 10^{6} \mathrm{CD} 34^{+}$cells/kg & $48(43.68 \%)$ \\
\hline Patients collecting $>5-10 \times 10^{6} \mathrm{CD} 34^{+}$cells $/ \mathrm{kg}$ & $28(30.76 \%)$ \\
\hline Patients collecting $<4 \times 10^{6} \mathrm{CD} 34^{+}$cells/kg & $15(25.56)$ \\
\hline Days of collection required $(\%):$ & \\
\hline 1 & $76(83.52 \%)$ \\
\hline 2 & $13(14.29 \%)$ \\
\hline 3 & $2(2.2 \%)$ \\
\hline Median CD34 $4^{+}$cells $/ \mathrm{kg} 10^{6}$ collected (range): & $33.73($ range: $2.39-84.93)$ \\
\hline Median days to neutrophil engraftment & $11.30(6-23)$ \\
\hline Median days to platelet engraftment & $13.92(7-30)$ \\
\hline
\end{tabular}

The median time to neutrophil engraftment was 11,3 days (min. 6 days- max.23 days), and the median time to a platelet count $>20.000$ for more than 7 days without transfusion were 13.92 days (min. 7 days- max.30 days). There was one patient who was defined as "poor engrafters," engrafting beyond one standard deviation, which was more than 23 days for neutrophils and 30 days for platelets (Table 2).

Antibacterial therapy was given about median 21 days after a febril neutropenic attack. The patients hospitalization time was median 32,48 days (min.19 days-max.63 days). Because of the high efficacy of this mobilization regimen and thus the very small number of "poor mobilizers", none of the following variables were associated with poor mobilization in this patient population: age, receipt of prior radiation therapy, duration of prior chemotherapy, BM cellularity\& disease involvement at the time of mobilization, peripheral white blood cell count and platelet count at the time of mobilization.

\section{Survival and relapse information}

Out of the total of 91 patients that had been followed for survival information, 8 have died and 83 were still alive at the time of analysis. The median follow-up time for survivors was 48 months. 10 patients have either relapsed ( 2 patients received lenalidomide treatment and 8 had a second autologous stem cell transplantation).

\section{Discussion}

It is widely accepted that the standard of care for treating certain patients with relapse/refracter lymphoma and MM includes highdose chemotherapy in conjunction with autologous HSCT $[18,19]$. There remains little consensus about the optimal method for mobilizing patients prior to autologous HSCT for MM, non-Hodgkin's lymphoma (NHL) and Hodgkin's lymphoma (HL). Although increasingly, there is recognition that some populations of patients are difficult to mobilize with a standard regimen of G-CSF alone [20].

The efficacy of G-CSF alone for mobilization of PBSCs for autoHSCT was established in a phase 3 study in which 58 patients with NHL or Hodgkin's lymhoma (HL) received either PBSCs mobilized with G-CSF $10 \mu \mathrm{g} / \mathrm{kg}$ s.c. daily for 6 consecutive days $(\mathrm{n}=27)$ or $\mathrm{BM}(\mathrm{n}=31)$ for hematopoietic reconstitution after HDT. A median value of $2.8 \times 10^{6}$ $\mathrm{CD} 34^{+}$cells $/ \mathrm{kg}$ was collected after G-CSF mobilization. Furthermore, when compared with BMT, reinfusion of G-CSF-mobilized PBSCs was found to reduce the number of plt infusions needed $(6 v s .10, \mathrm{P}=0.001)$ and the time to plt and neutrophil engraftment ( 16 days $v s .23$ days, $\mathrm{P}=$ 0.02 ; 11 days $v s$. 14 days, $\mathrm{P}=0.005$, respectively) $[21,22]$.

Nademanee et al. harvested stem cells in 95 patients with lymphoma after the s.c. or i.v. administration of regimens of G-CSF $10 \mathrm{mg} / \mathrm{kg}$ daily for a median of 12 days (range: $4-23 ; \mathrm{n}=39$ ), G-CSF $5 \mathrm{mg} / \mathrm{kg}$ daily for a median of 12 days (range: $8-27 ; \mathrm{n}=26$ ) or no mobilizing therapy $(\mathrm{n}=30)$. The authors reported median $\mathrm{CD} 34^{+}$cell yields of 6.2 $\times 10^{6} \mathrm{cells} / \mathrm{kg}, 3.4 \times 10^{6} \mathrm{cells} / \mathrm{kg}$ and $1.2 \times 10^{6} \mathrm{cells} / \mathrm{kg}$ in the respective treatment groups [23]. 28 mobilized stem cells in 22 patients with NHL or HL by using G-CSF $10 \mu \mathrm{g} / \mathrm{kg}$ s.c. daily for 4 days before the start of apheresis and reported a median $\mathrm{CD} 34^{+}$cell collection of $2.5 \times 10^{6}$ / $\mathrm{kg}$; approximately $50 \%$ of these patients required only one apheresis session, whereas $4 \%$ of patients required three sessions.

In many patients with MM or NHL, mobilization with G-CSF as a single agent results in suboptimal $\mathrm{CD} 34^{+}$cell yields. These studies show that $\mathrm{CD} 34^{+}$cell yields are generally lower when a cytokine-only mobilization regimen is used than when cytokine mobilization is used with chemotherapy. In addition, mobilization 'failures' (defined as $\mathrm{CD} 34^{+}$cell yields of $>2.0 \times 10^{6} / \mathrm{kg}$ ) were highly variable throughout these studies, ranging from 0 to $23 \%$.

In a study of 58 patients with NHL or HL [21], reported that mobilization with G-CSF alone $(10 \mu \mathrm{g} / \mathrm{kg}$ daily $)$ yielded significantly fewer $\mathrm{CD} 34^{+}$cells and was inferior to mobilization with chemotherapeutic agents plus G-CSF $\left(1.5 \times 10^{6} / \mathrm{kg} v s .6 .7 \times 10^{6} / \mathrm{kg}, \mathrm{P}\right.$ $=0.0002)$. Previous cycles of chemotherapy increased the risk of poor mobilization [21]. In a study of 52 patients with NHL [22], reported that mobilization with G-CSF alone ( $16 \mu \mathrm{g} / \mathrm{kg}$ s.c. daily for $4-6$ days) failed to yield adequate numbers of $\mathrm{CD} 34^{+}$cells in $35 \%$ of patients.

Efforts to determine factors associated with poor mobilization have focused largely on age, amount, and type of prior chemotherapy or biologic therapy, and amount of prior radiation therapy received $[17,24]$. For this reason, the International Myeloma Working Group (IMWG) has recently released suggested guidelines for stem cell collection in patients who have received prior therapy with novel agents. These include the use of early stem cell mobilization after 3 to 4 cycles of initial therapy or the addition of other mobilization agents in higher risk groups, such as patients who have received more than 4 cycles of therapy or who are older than 65 years of age [17]. Several prior studies have suggested that adding chemotherapy, most often Cytarabine (CY), to mobilization can improve cell yields when compared with G-CSF alone. One recent publication suggests that the addition of cyclophosphamide to G-CSF can overcome the effects of prior lenalidomide exposure. An alternative strategy that has been proposed to increase cell yields has been the addition of plerixafor (AMD3100) to G-CSF, an approach that was recently demonstrated 
Guner SI (2016) The high effect of chemomobilization with high-dose topside and G-CSF in autologous hematopoietic peripheral blood stem cell transplantation (Single centre experience)

to improve the chance of successful mobilization in comparison with G-CSF alone [17]. The safety profile of intermediate dose VP-16 and G-CSF appears acceptable, as more than $80 \%$ of the population don't require treatment for fever or supportive transfusions during the mobilization period [17].

In a study, 152 myeloma patients were mobilized with intermediate dose etoposide (VP-16; $375 \mathrm{mg} / \mathrm{m}^{2}$ on days 1 and2) and granulocytecolony stimulating factor (G-CSF) $(5 \mu \mathrm{g} / \mathrm{kg}$ twice daily from day 3 through the finalday of collection). The addition of VP-16 to G-CSF resulted in successful mobilization in $100 \%$ of patients, including 143 of them (94\%) who collected successfully in a single day. A total of $99 \%$ of patients, including those with prior XRT and/or prior lenalidomide or thalidomide therapy, collected at least $5 \times 10^{6}$ cells/kg in 1 or 2 days of apheresis, and the median total number of $\mathrm{CD} 34^{+}$cells collected in the entire population was $12 \times 10^{6}$ cells $/ \mathrm{kg}$. Collection was predictable, with $61 \%$ of patients collecting on day 11 , and the rest between days 7 and 13 [17]. In our study the median collected CD34 ${ }^{+}$cell number was $33,73 \times 10^{6}$ cells $/ \mathrm{kg}$

One potential advantage of the chemotherapy plus G-CSF approach is improved tumor control, as others have observed an antitumor effect in myeloma patients following the outpatient administration of VP-16 with G-CSF [16].

The timing of collection with VP-16 and G-CSF also appeared to be very predictable, with most patients collecting on 1 day. In our study 76 patients $(83,52 \%)$ of 91 patients stem cells were successfully collected after 1 mobilization. Our study group encompassed patients with various hematological malignancies. Most of the patients had received $>2$ lines treatment. The number of $\mathrm{CD} 34^{+}$cell yield in acute leukemia patients was relatively lower compared to patients with other disorders, which could not be statictically, documented due to small numbers of the patients study group. An Italian retrospective study reported that acute myeloid leukemia patients had the highest incidence of poor mobilization among patients with hematologic malignancies [18]. It is published that $10 \%-30 \%$ of non-Hodgkin lymhoma patients were reported to be hard-to-mobilize or experienced a mobilization failure with standard protocols [19]. On the other hand with a combination of CY and G-CSF, more than $95 \%$ of myeloma patients eligible for autologous stem cell transplantation could be successfully mobilized [6].

Our mobilization success was highly striking. On 76 patients $(83,52 \%)$ stem cells were successfully collected after 1 mobilization. The median collected $\mathrm{CD} 34^{+}$cell number was $33,73 \times 10^{6} \mathrm{cells} / \mathrm{kg}$. The high collected $\mathrm{CD} 34^{+}$cell number pickup the engratment of neutrofi and plt.

The side effects of mobilization chemotherapy were acceptable. Adverse effects of the regimen included supportive transfusions required in 59 patients $(64,83 \%)$, and 30 patients $(32,96 \%)$ with fever requiring hospitalization or intravenous antibiotics. Grade III or IV hematopoietic toxicity of chemotherapy had no significant effect on the mobilization efficacy. Supportive care and the incidence of febrile neutropenia were not significantly different from literature reported in CY plus G-CSF used mobilization regimen [17].

In conclusion, we demonstrated that high-dose etoposide plus G-CSF mobilization represents an effective and well tolerated chemomobilization for patients with various hematological malignancies and eligible for autologous transplantation. Collectively, all regimens in current usage fail to mobilize adequate numbers of $\mathrm{CD} 34^{+}$cells in $5-30 \%$ of patients. High failure rates can adversely affect patient outcomes, because these patients cannot proceed to transplantation without a repeat of mobilization and apheresis, which is associated with increased morbidity and resource utilization. Because of hese reasons, advances in mobilization strategies are needed to improve patient outcomes. Novel agents used in conjunction with existing therapies have the potential to amplify $\mathrm{CD}^{+} 4^{+}$cell yields without introducing additional toxicity, thereby improving the process of PBSC mobilization in patients undergoing auto-HSCT for MM or NHL and HL. The future of mobilization will use promising new agents in the context of a patient-tailored strategy that depends on individual disease characteristics and the nature of previous treatment.

\section{Guarantor of submission}

The corresponding author is the guarantor of submission.

The authors have not financial relationship with the organization that sponsored the research.

Patients approval received from each patient with approval from the Committee of clinical research ethics of University organization.

\section{References}

1. Pettengell R, Morgenstern GR, Woll PJ, Chang J, Rowlands M, et al. (1993) Periphera blood progenitor cell transplantation in lymphoma and leukemia using a single apheresis. Blood 82: 3770-3777.[Crossref]

2. Weaver CH, Hazelton B, Birch R, Palmer P, Allen C, et al. (1995) An analysis of engraftment kinetics as a function of the CD34 content of peripheral blood progenitor cell collections in 692 patients after the administration of myeloablative chemotherapy. Blood 86: 3961-3969.[Crossref]

3. Tricot G, Jagannath S, Vesole D, Nelson J, Tindle S, et al. (1995) Peripheral blood stem cell transplants for multiple myeloma: identification of favorable variables for rapid engraftment in 225 patients. Blood 85: 588-596.[Crossref]

4. Child JA, Morgan GJ, Davies FE, Owen RG, Bell SE, et al. (2003) High-dose chemotherapy with hematopoietic stem-cell rescue for multiple myeloma. $N$ Engl $J$ Med 348: 1875-1883.[Crossref]

5. Hari P, Pasquini MC, Vesole DH (2006) Cure of multiple myeloma -- more hype, less reality. BoneMarrow Transplant 37: 1-18.[Crossref]

6. Philip T, Guglielmi C, Hagenbeek A, Somers R, Van der Lelie H, et al. (1995) Autologous bone marrow transplantation as compared with salvage chemotherapy in relapses of chemotherapy-sensitive non-Hodgkin's lymphoma. $N$ Engl J Med 333 : 1540-1545.[Crossref]

7. Attal M, Harousseau JL, Stoppa AM, Sotto JJ, Fuzibet JG, et al. (1996) A prospective, randomized trial of autologous bone marrow transplantation and chemotherapy in multiple myeloma. IntergroupeFrançais du Myélome. N Engl J Med 335: 91-97. [Crossref]

8. Siena S, Schiavo R, Pedrazzoli P, Carlo-Stella C (2000) Therapeutic relevance of CD34 cell dose in blood cell transplantation for cancer therapy. J Clin Oncol 18: 1360-1377. [Crossref]

9. Solá C, Maroto P, Salazar R, Mesía R, Mendoza L, et al. (1999) Bone Marrow Transplantation: Prognostic Factors of Peripheral Blood Stem Cell Mobilization with Cyclophosphamide and Filgrastim (r-metHuG-CSF): The CD34+ Cell Dose Positively Affects the Time to Hematopoietic Recovery and Supportive Requirements after HighDose Chemotherapy. Hematology 4: 195-209.[Crossref]

10. Toor AA, Ayers J, Strupeck J, Parthasarathy M, Creech S, et al. (2004) Favourable results with a single autologous stem cell transplant following conditioning with busulphan and cyclophosphamide in patients with multiple myeloma. Br J Haemato 124: 769-776.[Crossref]

11. Alegre A, Tomas JF, Martinez-Chamorro C, Gil-Fernandez JJ, Fernandez-Villalta MJ, et al. (1997) Comparison of peripheral blood progenitor cell mobilization in patients with multiple myeloma: high-dose cyclophosphamide plus GM-CSF vs G-CSF alone. Bone Marrow Transplant 20: 211-217.[Crossref]

12. Hiwase DK, Bollard G, Hiwase S, Bailey M, Muirhead J, et al. (2007) Intermediatedose $\mathrm{CY}$ and G-CSF more efficiently mobilize adequate numbers of PBSC for tandem autologous PBSC transplantation compared with low-dose CY in patients with multiple myeloma. Cytotherapy 9: 539-547. [Crossref] 
13. Dingli D, Nowakowski GS, Dispenzieri A, Lacy MQ, Hayman S, et al. (2006) Cyclophosphamide mobilization does not improve outcome in patients receiving stem cell transplantation for multiple myeloma. Clin Lymphoma Myeloma 6: 384-388. [Crossref]

14. Ford CD, Greenwood J, Anderson J, Snow G, Petersen FB (2006) CD34+ cell adhesion molecule profiles differ between patients mobilized with granulocyte-colonystimulating factor alone and chemotherapy followed by granulocyte-colonystimulating factor. Transfusion 46: 193-198.[Crossref]

15. Pavone V, Gaudio F, Console G, Vitolo U, Iacopino P, et al. (2006) Poor mobilization is an independent prognostic factor in patients with malignant lymphomas treated by peripheral blood stem cell transplantation. Bone Marrow Transplant 37: 719-724. [Crossref]

16. Bolwell BJ, Pohlman B, Rybicki L, Sobecks R, Dean R, et al. (2007) Patients mobilizing large numbers of CD34+cells ('super mobilizers') have improved survival in autologousstem cell transplantation for lymphoid malignancies. Bone Marrow Transplant 40: 437-441.[Crossref]

17. Wood WA, Whitley J, Moore D, Sharf A, Irons R, et al. (2011) Chemomobilization with Etoposide is Highly Effective in Patients with Multiple Myeloma and Overcomes the Effects of Age and Prior Therapy. Biol Blood Marrow Transplant 17: 141-146. [Crossref]

18. Johnston A, Coiffier B (2008) HSCT for high-grade non-Hodgkin's lymphoma in adults. In: Apperley J, Carreras E, Gluckman E, Gratwohl A, Masszi T, editors. The EBMT handbook: haematopoietic stem cell transplantation. Paris: European School of Haematology. 435-440.
19. Zelenetz AD, Abramson JS, Advani RH, Andreadis CB, Byrd JC, et al. (2010)NCNN clinical practice guidelines in oncology: non-Hodgkin's lymphoma. J Natl Compr Canc Netw 8: 288-334.[Crossref]

20. Bensinger W, DiPersio JF, McCarty JM (2009) Improving stem cell mobilization strategies: future directions. Bone Marrow Transplant 43: 181-195.[Crossref]

21. Moskowitz CH, Glassman JR, Wuest D, Maslak P, Reich L, et al. (1998) Factors affecting mobilization of peripheral blood progenitor cells in patients with lymphoma Clin Cancer Res 4: 311-316.[Crossref]

22. Micallef IN, Apostolidis J, Rohatiner AZ, Wiggins C, Crawley CR, et al. (2000) Factors that predict unsuccessful mobilisation of peripheral blood progenitor cells following G-CSF alone in patients with non-Hodgkin's lymphoma. Hematol $J$ 1: 367-373.90. [Crossref]

23. Nademanee A, Sniecinski I, Schmidt GM, Dagis AC, O’Donnell MR, et al. (1994) High-dose therapy followed by autologous peripheral-blood stem-cell transplantation for patients with Hodgkin's disease and non-Hodgkin's lymphoma using unprimed and granulocyte colony-stimulating factor-mobilized peripheral-blood stem cells. $J$ Clin Oncol 12: 2176-2186.[Crossref]

24. Rohatiner AZ, Nadler L, Davies AJ, Apostolidis J, Neuberg D, et al. (2007) Myeloablative therapy with autologous bone marrow transplantation for follicular lymphoma at the time of second or subsequent remission: long-term follow-up. $J$ Clin Oncol 25: 2554-2559.[Crossref]

Copyright: $\odot 2016$ Guner SI. This is an open-access article distributed under the terms of the Creative Commons Attribution License, which permits unrestricted use, distribution, and reproduction in any medium, provided the original author and source are credited. 